\title{
Radiation recall pneumonitis induced by PD-1/PD-L1 blockades: mechanisms and therapeutic implications
}

\author{
Feifei Teng ${ }^{1}$, Min $\mathrm{Li}^{2}$ and Jinming $\mathrm{Yu}^{\mathrm{H}^{*}}$
}

\begin{abstract}
Background: The synergistic effect of radiotherapy (RT) in combination with immunotherapy has been shown in several clinical trials and case reports. The overlapping pulmonary toxicity induced by thoracic RT and programmed death 1/programmed death ligand-1 (PD-1/PD-L1) blockades is an important issue of clinical investigation in combination treatment. Thus far, the underlying mechanism of this toxicity remains largely unknown.

Main text: In this review, we discuss the unique pattern of radiation recall pneumonitis (RRP) induced by PD-1 blockade. The clinical presentation is different from common radiation pneumonitis (RP) or RRP induced by cytotoxic drugs. The immune checkpoint inhibitors may evoke an inflammatory reaction in patients' previously irradiated fields, with infiltrating lymphocytes and potential involvement of related cytokines. All RRP patients have showed durable response to anti-PD-1/PD-L1. RRP is manageable; however, interruption of checkpoint blockades is necessary and immunosuppressive treatment should be started immediately. Further analyses of the predictive factors, including RT dosimetric parameters, tumor-infiltrating lymphocytes (TILs), and PD-L1 expression, are needed given the wide use of immune checkpoint inhibitors and high mortality from lung toxicity with the combination treatment.
\end{abstract}

Conclusion: Immune checkpoint inhibitors may evoke an RRP in the patients' previously irradiated fields. Interactions between immune checkpoint inhibitors and radiotherapy should be studied further.

Keywords: Radiation recall pneumonitis, Radiation, Anti-PD-1/PD-L1, Lung cancer

\section{Background}

Programmed death 1 (PD-1) and programmed death ligand-1 (PD-L1) blockades have shown clinical activity and marked efficacy in the treatment of advanced nonsmall cell lung cancer (NSCLC). Several PD-1/PD-L1 blockades have been approved by the Food and Drug Administration (FDA) and the European Agency of Medicine (EAM) in the treatment of NSCLC [1-7]. Pembrolizumab has been approved as first-line treatment for advanced squamous or non-squamous NSCLC with PD-

\footnotetext{
*Correspondence: sdyujinming@163.com

'Department of Radiation Oncology, Shandong Cancer Hospital and Institute, Shandong First Medical University and Shandong Academy of Medical Sciences, 440 Jiyan Road, Jinan, China

Full list of author information is available at the end of the article
}

L1 expression $\geq 50 \%$ and as second-line treatment for advanced squamous or non-squamous NSCLC with PD-L1 expression $\geq 1 \%[8,9]$. The use of nivolumab and atezolizumab has been approved for advanced squamous or non-squamous NSCLC, independent of PD-L1 status, after at least one previous chemotherapy regimen $[2,10$ 12]. Durvalumab has been approved as consolidation therapy after chemo-radiotherapy in unresectable stage III NSCLC [13].

The synergistic effect of radiotherapy (RT) in combination with immunotherapy has been reported in several case reports and clinical trials $[14,15]$. Since the potential pulmonary toxicity induced by thoracic RT and PD-1/PDL1 blockades could overlap, pneumonitis is an important point of clinical investigation in combination treatment.

(c) The Author(s). 2020 Open Access This article is licensed under a Creative Commons Attribution 4.0 International License which permits use, sharing, adaptation, distribution and reproduction in any medium or format, as long as you give appropriate credit to the original author(s) and the source, provide a link to the Creative Commons licence, and indicate if changes were made. The images or other third party material in this article are included in the article's Creative Commons licence, unless indicated otherwise in a credit line to the material. If material is not included in the article's Creative Commons licence and your intended use is not permitted by statutory regulation or exceeds the permitted use, you will need to obtain permission directly from the copyright holder. To view a copy of this licence, visit http://creativecommons.org/licenses/by/4.0/. The Creative Commons Public Domain Dedication waiver (http://creativecommons.org/publicdomain/zero/1.0/) applies to the data made available in this article, unless otherwise stated in a credit line to the data. 
Thus far, the nature of this toxicity remains largely unknown. Herein, we discussed the unique pattern of radiation recall pneumonitis (RRP) induced by PD-1 blockade. With the dramatic increase in checkpoint immunotherapy usage, this new pattern of immunotherapy-related toxicity merits increased awareness with a focus on the clinical characteristics, underlying mechanisms, and management strategies.

\section{Main text}

\section{Clinical and patients characteristics}

Based on the previous trials and meta-analysis, all-grade and grade 3-4 pneumonitis occurred in $3-5 \%$ and $1 \%$, respectively, of patients with NSCLC who received PD1/PD-L1 blockades [10, 16, 17]. The incidence of pneumonitis may be higher when combined with RT, but the clinical data were limited. Louvel et al. reported two cases of pneumonitis in six patients who received concomitant PD-1/PD-L1 blockades with SBRT [18]. In a secondary analysis of the KEYNOTE-001 trial, which studied the use of pembrolizumab for patients with advanced NSCLC, all-grade pneumonitis occurred more frequently in patients who received previous thoracic RT than in those with no previous thoracic RT (63\% vs. 40\%) [19]. In the phase 2 randomized PEMBRO-RT trial, 92 patients were randomized to receive pembrolizumab either alone or after radiotherapy (3 fractions of 8 Gy) to a single tumor site. Pneumonitis occurred more often in the pembrolizumab combined with radiotherapy group than in the control group (26\% vs. $8 \%$ ) [15].

RRP is characterized by an inflammatory reaction within the previously treated radiation field after administration of specific treatment [20-22]. Most RRP reported previously was induced by chemotherapy, such as gemcitabine and taxanes. Immunotherapy-induced RRP was rarely reported and showed some differences from RRP induced by chemotherapy. First, according to previous literature $[23,24]$, the interval between the end of radiotherapy and diagnosis of immunotherapy-induced RRP could be nearly 2 years [23]. The corresponding intervals for RRP induced by chemotherapy ranged from 71 to 202 days [21]. Second, the patients with immunotherapy-induced RRP often had durable response to PD-1/PD-L1 blockades. In the two RRP cases reported by Shibaki et al., the corresponding intervals were 660 and 664 days; both of the cases showed a durable response [14]. In the study of Eze et al., all 3 patients achieved a durable response [15]. Although we cannot draw definitive conclusions based on the limited data [14, 15], this finding indicated that the occurrence of RRP might be related to favorable response to PD-1/PD-L1 blockade immunotherapy. However, chemoinduced RRP was not found to be related to the therapeutic effect of chemotherapy $[20,21,25]$.
Age $>70$ years and prior interstitial lung disease were reportedly associated with higher incidence of immunotherapy-related pneumonitis [26]. In a study conducted by Suresh et al., the risk of pneumonitis was higher for males than females, 0.25 vs. 0.19 per year [27]. In contrast, smoking status was not a risk factor in these patients [28]. In the above studies, the histology of squamous carcinoma was more common in patients with immunotherapyrelated pneumonitis [29]. In addition, the absence of extrathoracic metastases was associated with increased incidence of immunotherapy-related pneumonitis [26].

A study of 148 lung cancer patients who received definitive chemoradiation was reviewed to identify factors that may predict severe radiation pneumonitis (RP) [30]. The most significant factor for predicting RP was performance status. The incidence of severe RP was $16 \%$ for PS- 1 patients and $2 \%$ for PS- 0 patients, respectively. In addition, females were more likely to develop severe RP than males. Movsas et al. analyzed sociodemographic factors of 1450 patients treated in nine prospective RTOG trials [31]. They found that lower lobe primaries, presence of family with cancer, married relationship, and the interaction of female sex with low KPS status were associated with grade $\geq 3$ radiation pneumonitis. A history of smoking was another potential factor predictive of RP [32]. Previous radiation history was also associated with higher incidence of RP [33]. In a pooled analysis, 88 studies were included to study the risk factors for pneumonitis after RT of the thorax [34]. Patient age and tumor size were significantly associated with rate of grade 2 or greater RP. However, histology, GTV, PTV, and tumor location (central versus peripheral) were not significant.

Considering the indicators for immunotherapy-related pneumonitis and radiation pneumonitis, older patients with large tumor size, low KPS status, and prior interstitial lung disease should be cautious about the occurrence of RRP.

\section{Therapy regimens}

Based on previous studies, immunotherapy was often delivered after thoracic RT. The interval between thoracic RT and immunotherapy varied from 1 day to 11.5 months, and the incidence of pneumonitis was between 0 and $17 \%[13,15,19]$. It seemed there were no relationships between the rate of pneumonitis and the time intervals between RT and anti-PD-1/PD-L1 treatment, but further studies are needed to clarify the associations between pneumonitis and therapy regimens that are delivered sequentially and concomitantly.

A higher incidence of pneumonitis was reported with the use of PD-1 inhibitors compared with PD-L1 inhibitors and in treatment-naïve patients [16]. The PD-1/PDL2 interactions with PD-1 inhibitors might be the reason 
for the higher incidence of pneumonitis in PD-1 inhibitors. Preclinical experiments suggested that PD-1 blockades may increase PD-L2 availability for binding to repulsive guidance molecule $b$ (RGMb), which could lead to pneumonitis [35].

\section{RT dosimetric factors}

RT dose and fractionation, which often affect clinical management decisions with respect to tumor control and lung tolerance, are important. Dosimetric parameters have been widely assessed as predictors for the development of radiation pneumonitis. In a study conducted by Jenkins and Watts, dosimetric parameters, pulmonary function, and clinical parameters were analyzed in patients who received RT at the same dose and with an identical technique for NSCLC. The fractional volume of lung receiving >5-20 Gy, mean lung dose (MLD), absolute volume of lung spared from receiving $>5-15 \mathrm{~Gy}$, craniocaudal position of the isocenter, total lung capacity, and transfer coefficient for carbon monoxide (KCOc) were significantly correlated with the risk of pneumonitis [36]. As reported, MLD of $15 \mathrm{~Gy}, 17.5$ to $20 \mathrm{~Gy}, 22.5$ to $25 \mathrm{~Gy}$, and 27.5 Gy resulted in $0 \%, 13 \%, 21 \%$, and $43 \%$ incidence of all grades of RP, respectively [37]. In a metaanalysis, MLD and the percent volume of the total lung receiving a dose greater than 20 Gy (V20) were significant factors for higher risk of grade 2 or greater RP. Another study demonstrated that MLD from total lung excluding-plan target volume (Lung-PTV) may be more accurate and promising to predict acute symptomatic radiation pneumonitis in intensitymodulated radiation therapy (IMRT)-treated lung cancer patients [38]. With the development of radiation equipment, IMRT and stereotactic body radiation therapy (SBRT) have been widely used in the treatment of lung cancer. The incidence of grade $\geq 3 \mathrm{RP}$ was lower when using IMRT than when using 3dimensional techniques (3DCRT), since IMRT could allow for extensive reductions of radiation dose to normal lung tissues [39]. MLD and the volume of the total lung receiving a dose greater than 5, 7, and 10 Gy were also associated with RP for SBRT [40]. In addition, proton beam therapy has been increasingly used for the treatment of lung cancer and may further reduce radiation dose to normal lung tissues and reduce the risk of RP [41]. As for immunotherapyrelated pneumonitis, in a retrospective study, the relationship between chest-RT and development of immune-related pneumonitis in NSCLC patients treated with anti-PD-1/PD-L1 was analyzed. However, no RT parameter was significantly associated with pneumonitis [42]. Since RP is correlated with the dose delivered to a particular fractional volume of the lung, RT dose and fractionation, especially MLD, deserve attention and potential pneumonitis should be monitored in patients receiving combination treatment.

\section{Radiographic patterns}

In the majority of RRP cases, the area of pneumonitis matched the irradiated area. The most common radiographic pattern of RRP on chest CT was the cryptogenic organizing pneumonia (COP) pattern, followed by the non-specific interstitial pneumonia (NSIP) pattern, the hypersensitivity pneumonitis (HP) pattern, and the acute interstitial pneumonia (AIP)/acute respiratory distress syndrome (ARDS) pattern. The radiographic patterns were associated with volume of irradiated area and the toxicity grades of RRP. AIP/ARDS was correlated with the highest grade (grade 3), then the COP pattern as grade 2, and the HP and NSIP patterns had the lowest grade 1 . Ground glass opacities (GGO), reticular opacities, and consolidations were observed in some cases of RRP.

\section{Underlying mechanisms}

Thoracic radiotoxicities can produce both acute and long-term lung toxicities that occur months to years after treatment. Around 15\% of patients experience pneumonitis within 2 to 3 months after thoracic RT [43, 44]. Pulmonary fibrosis can be considered a recovery of lung injury after radiation. The gamma delta $\mathrm{T}$ cells $(\gamma \delta \mathrm{T})$ cells help prevent progression of fibrosis and suppress $\mathrm{CD}^{+}$cell recruitment [45]. Several groups have found abundant lymphocytes infiltrating the lung tissues and elevated CD4/CD8 ratios in bronchoalveolar lavage fluid from patients with radiation pneumonitis [43, 4650]. In addition, the $\mathrm{T}$ helper type 22 (TH22) and follicular helper T (TFH) cells may have possible effects on the host defense against bacteria and viruses in the lung $[51,52]$. Previously, it was assumed that immunotherapy via PD-1/PD-L1 blockade works by reinvigorating preexisting exhausted tumor-infiltrating lymphocytes (TILs). Recently, it was indicated that the majority of tumor-specific TILs after immunotherapy have $\mathrm{T}$ cell receptors (TCRs) that were not identified pre-treatment, suggesting that the TILs are newly recruited posttherapy [53]. A dynamic monitoring of the changes of the specific $\mathrm{T}$ cell populations and phenotypes during immunotherapy in previous irradiated models could help monitoring the RRP and the anti-tumor response.

Transforming growth factor $\beta$ (TGF- $\beta$ ) plays a part in progression of radiation-related fibrosis [54]. Rube and Chen et al. observed that the serum levels of TGF- $\beta$ and IL-6 were elevated prior to and after radiotherapy and correlated with radiation-induced pneumonitis $[55,56]$. Tumor necrosis factor (TNF)- $\alpha$ leads to TGF- $\beta 1$ induction and is known to contribute to fibrosis development 
[57]. Hence, it has become a target molecule to monitor the progression of fibrosis. The cytotoxic actions of TNF also play an important role in anti-PD-L1 treatment. Nuclear factor-kB (NF-kB) signaling is crucial in regulating the production of TNF- $\alpha$, which was associated with the function of cytotoxic $\mathrm{T}$ lymphocytes and maturation of dendritic cells in the use of PD-1/PD-L1 blockades for cancer treatment [58]. Elevated TNF was observed with a combination treatment of anti-PD-L1 and radiation [59]. The potential synergy may also activate inflammation-mediated injury.

In addition, interleukins (IL)-4, IL-6, IL-10, IL-13, IL17 , and IL-18 are demonstrated to be associated with radiation-related pneumonitis and the therapeutic effects of anti-PD-1/PD-L1 [60]. Buttner et al. observed increased IL-4 gene transcription and synthesis in lung tissues after radiation, and substantial IL-4 secretion by macrophages in radiation-induced fibrosis [61]. Wilson et al. demonstrated that IL-17A gene knockout could decrease the severity of lung injury in mice, demonstrating the important role of IL-17A in fibrosis and inflammation [62]. IL-4 and IL-13 were also shown to facilitate fibrosis by promoting TGF- $\beta$ [63]. This finding may explain the associations between RRP and response to anti-PD-1/PD-L1 in our case and previous reports. The cytokines resulting in pneumonitis also play a pivotal role in PD-1/PD-L1 blockade immunotherapy.

Brickey et al. investigated the role of myeloid differentiation primary response 88 (MyD88) in regulating nuclear factor kappa-B (NF-kB) activating responses and innate immunity in post-radiation lung tissues. They found that MyD88 was instrumental for regulating inflammatory processes that aid in recovery from radiation $[55,64]$. The activation of cGMP-AMP synthase-stimulator of interferon genes (cGAS-STING) signaling and ROS/RNS also plays an important role in lung injury mediated by noninfectious inflammatory processes $[65,66]$. The major signaling pathways involved in immunotherapy-induced RRP are shown in Fig. 1. The activations and interactions of these inflammatory-related signals also contributed to the therapeutic effects of anti-PD-1/PD-L1, with or without radiotherapy. Anti-PD-1/PD-L1 therapy may have evoked an inflammatory reaction mediated by the lymphocytes, cytokines, and proteins as a result of radiation exposure in patients' previously irradiated fields (Fig. 2).

\section{Immunologic factors}

Understanding the molecular and cellular processes of RRP helps in finding biomarkers that predict the risk for developing radiation pneumonitis during checkpoint immunotherapy. Tumor-infiltrating lymphocytes (TILs) were strongly associated with response to anti-PD-1/PDL1 immunotherapies [67]. Since increased rates of lymphocytes, macrophage, and neutrophils were found in

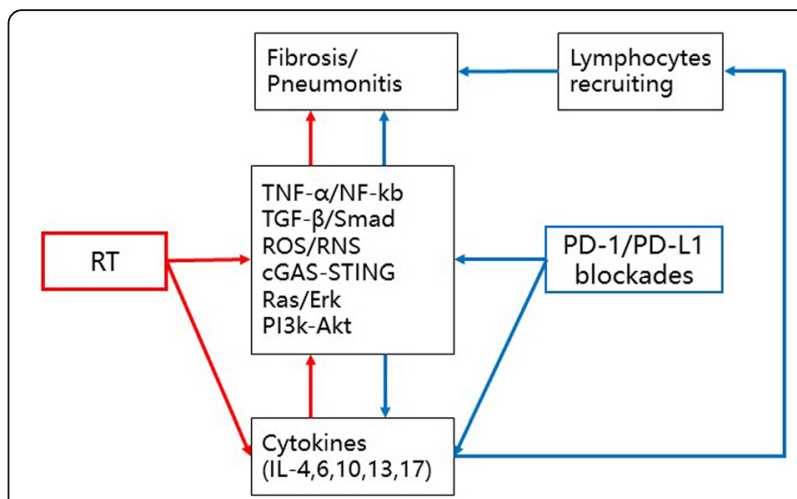

Fig. 1 Cytokines and relative signaling pathways potentially involved in RRP. Tumor necrosis factor-a (TNF-a); transforming growth factor $\beta$ (TGF- $\beta$ ); interleukins 4, 6, 10, 13, 17, and $18(\mathrm{IL}-4,6,10,13,17,18)$; myeloid differentiation primary response 88 (MyD88); CGMP-AMP synthase (cGAS)-stimulator of interferon genes (STING); nuclear factor kappa-light-chain-enhancer of activated B cells (NF-kB); reactive oxygen species/reactive nitrogen species (ROS/RNS); extracellular regulated protein kinases (Erk); and phosphatidylinositol 3-kinase (PI3K)

bronchoalveolar lavage (BAL) fluid from the majority of RPP patients, high TILs are most likely associated with RRP. However, the predictive effect was limited by the invasive operation. A number of researchers have reported the predictive effects of circulating lymphocytes [68-70]. The percentage of circulating $\mathrm{B}$ cells and $\mathrm{T}$ lymphocytes may reflect the body's immune status and may be a potential therapeutic target for the treatment of pneumonitis [71]. Further, circulating and lung Th17 cells contributed to pulmonary fibrosis and inflammation [72]. An imbalance of circulating Th17 cells and regulatory $\mathrm{T}$ (Treg) cells was associated with the deterioration of pulmonary injury [73].

Transforming growth factor $\alpha$ (TGF- $\alpha$ ), a protein coded by the TGFA gene, was a potential biomarker for RRP. TGF- $\alpha$ was able to induce lung fibroblasts to myofibroblasts and to stimulate collagen synthesis [74, 75]. Plasma TGF- $\alpha$ levels could be used to stratify patients into groups at low, intermediate, and high risk to develop RP $[76,77]$. Monitoring plasma TGF- $\alpha$ levels may be useful to predict RRP during the course of PD-1/PDL1 blockades.

IL-6 is an important cytokine responsible for inflammation and RRP development [78]. It is synthesized and secreted by various lung parenchyma cells and regulates inflammatory and immune responses [79]. Hence, levels of serum IL- 6 could be used to estimate the inflammatory status of the lung. However, immunotherapy could also increase the level of IL-6, especially in good responders, which may disturb its predictive effects [80].

As a pivotal molecular target during treatment of antiPD-1/PD-L1, PD-L1 expression has been of concern. Expression of $\mathrm{PD}-1 / \mathrm{PD}-\mathrm{L} 1$ in lung tissue may be related to 


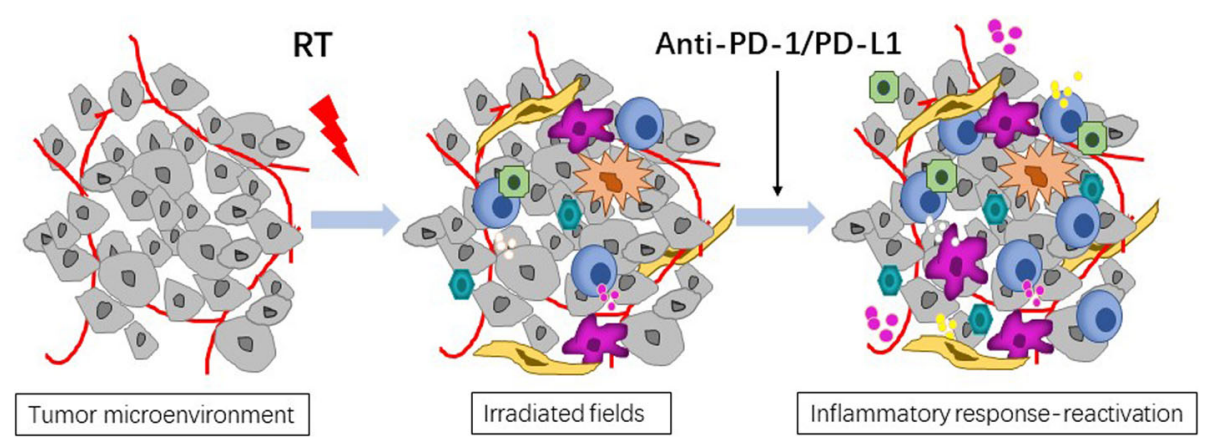

Fig. 2 Immune mechanisms of RRP triggered by anti-PD-1/PD-L1. The immune checkpoint inhibitors evoke an inflammatory reaction in previously irradiated fields

immune-related pneumonitis. With limited data, we cannot draw conclusions about the association of PD-1 or PD-L1 expression with pneumonitis. Since the host immune status plays an important role in both therapeutic effects and lung injury with radiation combined with anti-PD-1/PD-L1, further studies are needed to evaluate its predictive effect.

\section{Management strategies}

Steroids and corticosteroids have been widely used in different inflammatory diseases, such as radiation pneumonitis and some autoimmune diseases. Prednisone, which could improve lung function and minimize lung tissue toxicity and symptoms of radiation-induced pneumonitis, was the most commonly used drug [81]. In grade 1 to 2 pneumonitis, treatment consists of oral steroids with prednisone $1 \mathrm{mg} / \mathrm{kg} /$ day or equivalent. Steroids should be tapered over 4 to 6 weeks after recovery, and rechallenge of immunotherapy should be delayed until the dose of steroids equals $10 \mathrm{mg}$ of oral prednisone per day or less. In grade 3 to 4 pneumonitis, treatment should consist of high-dose i.v. corticosteroids with prednisolone $2-4 \mathrm{mg} / \mathrm{kg}$ daily or equivalent and immunotherapy should be discontinued permanently. If there is no improvement in patient's condition or imaging, additional immunosuppressive strategies should be implemented. Tapering of steroids should be careful and slow, over 6 weeks or more [82]. Also, concurrent broad-spectrum antibiotics are recommended because of the potential for overlapping presentation and infection $[83,84]$.

In addition to steroids and corticosteroids as the mainstay of treatment, angiotensin-converting enzyme inhibitor could potentially reduce the risk of symptomatic radiation pneumonitis in male patients and patients receiving low MLD with NSCLC $[85,86]$. Oxygen therapy was suggested as a supportive therapy. It could relieve breathlessness by increasing the oxygen in blood and in tissues. Further, some molecular approaches targeting the intermediates involved in the development of inflammatory response in the lungs, such as DNA intercalator and anti-TGF- $\beta$ type 1 receptor, were studied in preclinical practice $[87,88]$.

\section{Conclusions}

In conclusion, RRP induced by PD- 1 blockade is the unique pattern of radiation-related toxicity. The clinical presentation was different from common RP and RRP induced by cytotoxic drugs. The immune checkpoint inhibitors may have evoked an inflammatory reaction in patients' previously irradiated fields, with potential involvement of infiltrating lymphocytes and related cytokines. All RRP patients showed durable response to antiPD-1/PD-L1. It was manageable, and sufficient steroids or corticosteroids are needed. A further analysis of the predictive factors is needed with the wide use of immune checkpoint inhibitors and high mortality of this kind of lung toxicity with combination treatment.

\section{Abbreviations}

AIP: Acute interstitial pneumonia; ARDS: Acute respiratory distress syndrome; BAL: Broncho-alveolar lavage; COP: Cryptogenic organizing pneumonia; COPD: Chronic obstructive pulmonary disease; CTCs: Circulating tumor cells; HP: Hypersensitivity pneumonitis; IL-4, 6, 10, 13, 17, 18: Interleukins 4, 6, 10, 13, 17, 18; KCOc: Carbon monoxide; MLD: Mean lung dose; Myd88: Myeloid differentiation primary response 88; NF-kb: Nuclear factor kappa-light-chainenhancer of activated B cells; NSCLC: Non-small cell lung cancer; NSIP: Nonspecific interstitial pneumonia; PD-1: Programmed death 1; PD-

L1: Programmed death ligand-1; PTV: Plan target volume; RGMB: Repulsive guidance molecule b; ROS/RNS: Reactive oxygen species/reactive nitrogen species; RRP: Radiation recall pneumonitis; RT: Radiotherapy; cGAS-

STING: Cgmp-AMP synthase-stimulator of interferon genes; TFH: Follicular helper T cell; TGF- $\beta$ : Transforming growth factor $\beta$; TH22: T helper type 22; TILs: Tumor-infiltrating lymphocytes; TNF-a: Tumor necrosis factor-a;

Treg: Regulatory T; үठT: Gamma delta T cells

\section{Acknowledgements}

None.

Authors' contributions

J.M.Y. designed the study; F.F.T. collected the data and drafted the article. F.F.T, M. L, and J.M.Y. reviewed and revised the manuscript. All authors read and approved the final manuscript. 


\section{Funding}

This work was supported by grants from the National Natural Science Foundation of China (NSFC 81803066) to F.F.T. and National Natural Science Foundation of China (NSFC 81972863) to J.M.Y.

\section{Availability of data and materials}

All data generated or analyzed during this study are included in this published article.

\section{Ethics approval and consent to participate}

The study has been reviewed and approved by the Ethics Committee of Shandong Cancer Hospital and Institute, China. This study has been conducted according to the Declaration of Helsinki.

\section{Consent for publication}

Not applicable.

\section{Competing interests}

The authors have no disclosures. Dr. Min Li is a Board Member for the Journal of BMC Medicine.

\section{Author details}

${ }^{1}$ Department of Radiation Oncology, Shandong Cancer Hospital and Institute, Shandong First Medical University and Shandong Academy of Medical Sciences, 440 Jiyan Road, Jinan, China. ²Department of Surgery, Department of Medicine, The University of Oklahoma Health Sciences Center, Oklahoma City, OK, USA.

\section{Received: 14 May 2020 Accepted: 24 July 2020}

Published online: 18 September 2020

\section{References}

1. Dang TO, Ogunniyi A, Barbee MS, Drilon A. Pembrolizumab for the treatment of PD-L1 positive advanced or metastatic non-small cell lung cancer. Expert Rev Anticancer Ther. 2016;16(1):13-20.

2. Rittmeyer A, Barlesi F, Waterkamp D, Park K, Ciardiello F, von Pawel J, Gadgeel SM, Hida T, Kowalski DM, Dols MC, et al. Atezolizumab versus docetaxel in patients with previously treated non-small-cell lung cancer (OAK): a phase 3, open-label, multicentre randomised controlled trial. Lancet. 2017:389(10066):255-65.

3. Horn L, Spigel DR, Vokes EE, Holgado E, Ready N, Steins M, Poddubskaya E, Borghaei H, Felip E, Paz-Ares L, et al. Nivolumab versus docetaxel in previously treated patients with advanced non-small-cell lung cancer: twoyear outcomes from two randomized, open-label, phase III trials (CheckMate 017 and CheckMate 057). J Clin Oncol. 2017;35(35):3924-33.

4. Mok TSK, Wu YL, Kudaba I, Kowalski DM, Cho BC, Turna HZ, Castro G Jr, Srimuninnimit V, Laktionov KK, Bondarenko I, et al. Pembrolizumab versus chemotherapy for previously untreated, PD-L1-expressing, locally advanced or metastatic non-small-cell lung cancer (KEYNOTE-042): a randomised, open-label, controlled, phase 3 trial. Lancet. 2019;393(10183):1819-30.

5. Reck M, Rodriguez-Abreu D, Robinson AG, Hui R, Csoszi T, Fulop A, Gottfried M, Peled N, Tafreshi A, Cuffe S, et al. Updated analysis of KEYNOTE-024: pembrolizumab versus platinum-based chemotherapy for advanced nonsmall-cell lung cancer with PD-L1 tumor proportion score of 50\% or greater. J Clin Oncol. 2019;37(7):537-46.

6. Remon J, Besse B, Soria JC. Successes and failures: what did we learn from recent first-line treatment immunotherapy trials in non-small cell lung cancer? BMC Med. 2017;15(1):55.

7. Farkona S, Diamandis EP, Blasutig IM. Cancer immunotherapy: the beginning of the end of cancer? BMC Med. 2016;14:73.

8. Reck M, Rodriguez-Abreu D, Robinson AG, Hui R, Csoszi T, Fulop A, Gottfried M, Peled N, Tafreshi A, Cuffe S, et al. Pembrolizumab versus chemotherapy for PD-L1-positive non-small-cell lung cancer. N Engl J Med. 2016;375(19): 1823-33.

9. Garon EB, Rizvi NA, Hui R, Leighl N, Balmanoukian AS, Eder JP, Patnaik A, Aggarwal C, Gubens M, Horn L, et al. Pembrolizumab for the treatment of non-small-cell lung cancer. N Engl J Med. 2015;372(21):2018-28.

10. Brahmer J, Reckamp KL, Baas P, Crino L, Eberhardt WE, Poddubskaya E, Antonia S, Pluzanski A, Vokes EE, Holgado E, et al. Nivolumab versus docetaxel in advanced squamous-cell non-small-cell lung cancer. N Engl J Med. 2015;373(2):123-35.
11. Borghaei H, Paz-Ares L, Horn L, Spigel DR, Steins M, Ready NE, Chow LQ, Vokes EE, Felip E, Holgado E, et al. Nivolumab versus docetaxel in advanced nonsquamous non-small-cell lung cancer. N Engl J Med. 2015;373(17):1627-39.

12. Fehrenbacher $L$, Spira A, Ballinger M, Kowanetz M, Vansteenkiste J, Mazieres J, Park K, Smith D, Artal-Cortes A, Lewanski C, et al. Atezolizumab versus docetaxel for patients with previously treated non-small-cell lung cancer (POPLAR): a multicentre, open-label, phase 2 randomised controlled trial. Lancet. 2016;387(10030):1837-46.

13. Antonia SJ, Villegas A, Daniel D, Vicente D, Murakami S, Hui R, Yokoi T, Chiappori A, Lee KH, de Wit M, et al. Durvalumab after chemoradiotherapy in stage III non-small-cell lung cancer. N Engl J Med. 2017;377(20):1919-29.

14. Postow MA, Callahan MK, Barker CA, Yamada Y, Yuan J, Kitano S, Mu Z, Rasalan T, Adamow M, Ritter E, et al. Immunologic correlates of the abscopal effect in a patient with melanoma. N Engl J Med. 2012;366(10): 925-31.

15. Theelen W, Peulen HMU, Lalezari F, van der Noort V, de Vries JF, Aerts J, Dumoulin DW, Bahce I, Niemeijer AN, de Langen AJ, et al. Effect of pembrolizumab after stereotactic body radiotherapy vs pembrolizumab alone on tumor response in patients with advanced non-small cell lung cancer: results of the PEMBRO-RT phase 2 randomized clinical trial. JAMA Oncol. 2019;5(9):1276-82.

16. Khunger M, Rakshit S, Pasupuleti V, Hernandez AV, Mazzone P, Stevenson J, Pennell NA, Velcheti $V$. Incidence of pneumonitis with use of programmed death 1 and programmed death-ligand 1 inhibitors in non-small cell lung cancer: a systematic review and meta-analysis of trials. Chest. 2017;152(2): 271-81.

17. Naidoo J, Wang X, Woo KM, lyriboz T, Halpenny D, Cunningham J, Chaft JE, Segal NH, Callahan MK, Lesokhin AM, et al. Pneumonitis in patients treated with anti-programmed death-1/programmed death ligand 1 therapy. J Clin Oncol. 2017:35(7):709-17.

18. Louvel G, Bahleda R, Ammari S, Le Pechoux C, Levy A, Massard C, Le Pavec J, Champiat S, Deutsch E. Immunotherapy and pulmonary toxicities: can concomitant immune-checkpoint inhibitors with radiotherapy increase the risk of radiation pneumonitis? Eur Respir J. 2018;51(1). https://doi.org/10. 1183/13993003.01737-2017.

19. Shaverdian N, Lisberg AE, Bornazyan K, Veruttipong D, Goldman JW Formenti SC, Garon EB, Lee P. Previous radiotherapy and the clinical activity and toxicity of pembrolizumab in the treatment of non-small-cell lung cancer: a secondary analysis of the KEYNOTE-001 phase 1 trial. Lancet Oncol. 2017;18(7):895-903.

20. Faiz SA, Balachandran DD, Bashoura L, Shannon VR. Pulmonary radiation recall induced by gemcitabine. Am J Respir Crit Care Med. 2016;194(7):909-10.

21. Ding X, Ji W, Li J, Zhang X, Wang L. Radiation recall pneumonitis induced by chemotherapy after thoracic radiotherapy for lung cancer. Radiat Oncol. 2011;6:24.

22. Jeter MD, Janne PA, Brooks S, Burstein HJ, Wen P, Fuchs CS, Loeffler JS, Devlin PM, Salgia R. Gemcitabine-induced radiation recall. Int J Radiat Oncol Biol Phys. 2002;53(2):394-400.

23. Shibaki R, Akamatsu H, Fujimoto M, Koh Y, Yamamoto N. Nivolumab induced radiation recall pneumonitis after two years of radiotherapy. Ann Oncol. 2017;28(6):1404-5.

24. Manapov F, Roengvoraphoj O, Dantes M, Marschner S, Li M, Eze C. Pneumonitis in irradiated lungs after nivolumab: a brief communication and review of the literature. J Immunother. 2018;41(2):96-9.

25. Ge J, Verma V, Hollander A, Langer C, Simone CB 2nd. Pemetrexed-induced radiation recall dermatitis in a patient with lung adenocarcinoma: case report and literature review. J Thorac Dis. 2016;8(12):E1589-93.

26. Cho JY, Kim J, Lee JS, Kim YJ, Kim SH, Lee YJ, Cho YJ, Yoon HI, Lee JH, Lee $C T$, et al. Characteristics, incidence, and risk factors of immune checkpoint inhibitor-related pneumonitis in patients with non-small cell lung cancer. Lung Cancer. 2018;125:150-6.

27. Suresh K, Voong KR, Shankar B, Forde PM, Ettinger DS, Marrone KA, Kelly RJ, Hann CL, Levy B, Feliciano JL, et al. Pneumonitis in non-small cell lung cancer patients receiving immune checkpoint immunotherapy: incidence and risk factors. J Thorac Oncol. 2018;13(12):1930-9.

28. Kato T, Masuda N, Nakanishi Y, Takahashi M, Hida T, Sakai H, Atagi S, Fujita S, Tanaka H, Takeda K, et al. Nivolumab-induced interstitial lung disease analysis of two phase II studies patients with recurrent or advanced nonsmall-cell lung cancer. Lung Cancer. 2017;104:111-8.

29. Yamaguchi T, Shimizu J, Hasegawa T, Horio Y, Inaba Y, Yatabe Y, Hida T. Preexisting pulmonary fibrosis is a risk factor for anti-PD-1-related pneumonitis 
in patients with non-small cell lung cancer: a retrospective analysis. Lung Cancer. 2018;125:212-7.

30. Robnett TJ, Machtay M, Vines EF, McKenna MG, Algazy KM, McKenna WG. Factors predicting severe radiation pneumonitis in patients receiving definitive chemoradiation for lung cancer. Int J Radiat Oncol Biol Phys. 2000; 48(1):89-94.

31. Movsas BSS, Curran WJ Jr. Sociodemographic factors are significant predictors of toxicity in RTOG non-operative NSCLC trials. Int J Radiat Oncol Biol Phys. 2006;66(3):S62. November 01, 2006.

32. Monson JM, Stark P, Reilly JJ, Sugarbaker DJ, Strauss GM, Swanson SJ, Decamp MM, Mentzer SJ, Baldini EH. Clinical radiation pneumonitis and radiographic changes after thoracic radiation therapy for lung carcinoma. Cancer. 1998:82(5):842-50.

33. Movsas B, Raffin TA, Epstein AH, Link CJ Jr. Pulmonary radiation injury. Chest. 1997:111(4):1061-76.

34. Graham MV, Purdy JA, Emami B, Harms W, Bosch W, Lockett MA, Perez CA. Clinical dose-volume histogram analysis for pneumonitis after 3D treatment for non-small cell lung cancer (NSCLC). Int J Radiat Oncol Biol Phys. 1999; 45(2):323-9.

35. Xiao Y, Yu S, Zhu B, Bedoret D, Bu X, Francisco LM, Hua P, Duke-Cohan JS, Umetsu DT, Sharpe AH, et al. RGMb is a novel binding partner for PD-L2 and its engagement with PD-L2 promotes respiratory tolerance. J Exp Med. 2014;211(5):943-59.

36. Jenkins $P$, Watts J. An improved model for predicting radiation pneumonitis incorporating clinical and dosimetric variables. Int J Radiat Oncol Biol Phys. 2011;80(4):1023-9.

37. Oetzel D, Schraube P, Hensley F, Sroka-Perez G, Menke M, Flentje M. Estimation of pneumonitis risk in three-dimensional treatment planning using dose-volume histogram analysis. Int J Radiat Oncol Biol Phys. 1995; 33(2):455-60.

38. Meng $Y$, Yang $H$, Wang W, Tang $X$, Jiang C, Shen Y, Luo W. Excluding PTV from lung volume may better predict radiation pneumonitis for intensity modulated radiation therapy in lung cancer patients. Radiat Oncol. 2019; 14(1):7.

39. Liao ZX, Komaki RR, Thames HD Jr, Liu HH, Tucker SL, Mohan R, Martel MK, Wei X, Yang K, Kim ES, et al. Influence of technologic advances on outcomes in patients with unresectable, locally advanced non-small-cell lung cancer receiving concomitant chemoradiotherapy. Int J Radiat Oncol Biol Phys. 2010;76(3):775-81.

40. Kyas I, Hof H, Debus J, Schlegel W, Karger CP. Prediction of radiationinduced changes in the lung after stereotactic body radiation therapy of non-small-cell lung cancer. Int J Radiat Oncol Biol Phys. 2007:67(3):768-74.

41. Higgins KA, O'Connell K, Liu Y, Gillespie TW, McDonald MW, Pillai RN, Patel KR, Patel PR, Robinson CG, Simone CB 2nd, et al. National Cancer Database analysis of proton versus photon radiation therapy in non-small cell lung cancer. Int J Radiat Oncol Biol Phys. 2017;97(1):128-37.

42. Voong KR, Hazell SZ, Fu W, Hu C, Lin CT, Ding K, Suresh K, Hayman J, Hales RK, Alfaifi $\mathrm{S}$, et al. Relationship between prior radiotherapy and checkpoint-inhibitor pneumonitis in patients with advanced non-small-cell lung cancer. Clin Lung Cancer. 2019;20(4):e470-e479. https://doi.org/10.1016/j.cllc.2019.02.018.

43. Boffetta P. Epidemiology of environmental and occupational cancer Oncogene. 2004;23(38):6392-403.

44. Travis LB, Gospodarowicz M, Curtis RE, Clarke EA, Andersson M, Glimelius B, Joensuu T, Lynch CF, van Leeuwen FE, Holowaty E, et al. Lung cancer following chemotherapy and radiotherapy for Hodgkin's disease. J Natl Cancer Inst. 2002;94(3):182-92.

45. Simonian PL, Wehrmann F, Roark CL, Born WK, O'Brien RL, Fontenot AP. gammadelta T cells protect against lung fibrosis via IL-22. J Exp Med. 2010; 207(10):2239-53.

46. Zhang W, Becciolini A, Biggeri A, Pacini P, Muirhead CR. Second malignancies in breast cancer patients following radiotherapy: a study in Florence, Italy. Breast Cancer Res. 2011;13(2):R38.

47. Amos Cl, Wu X, Broderick P, Gorlov IP, Gu J, Eisen T, Dong Q, Zhang Q, Gu $X$, Vijayakrishnan J, et al. Genome-wide association scan of tag SNPS identifies a susceptibility locus for lung cancer at 15q25.1. Nat Genet. 2008; 40(5):616-22.

48. Bernier J, Hall EJ, Giaccia A. Radiation oncology: a century of achievements. Nat Rev Cancer. 2004;4(9):737-47.

49. Li $X$, Hemminki K. Inherited predisposition to early onset lung cancer according to histological type. Int J Cancer. 2004;112(3):451-7.
50. Hwang SJ, Cheng LS, Lozano G, Amos Cl, Gu X, Strong LC. Lung cancer risk in germline p53 mutation carriers: association between an inherited cancer predisposition, cigarette smoking, and cancer risk. Hum Genet. 2003;113(3): 238-43.

51. Boyden AW, Legge KL, Waldschmidt TJ. Pulmonary infection with influenza A virus induces site-specific germinal center and T follicular helper cell responses. PLoS One. 2012;7(7):e40733.

52. Ying $X$, Su Z, Bie Q, Zhang $P$, Yang $H$, Wu Y, Xu Y, Wu J, Zhang $M$, Wang $S$, et al. Synergistically increased ILC2 and Th9 cells in lung tissue jointly promote the pathological process of asthma in mice. Mol Med Rep. 2016; 13(6):5230-40

53. Callahan MK, Wolchok JD. Recruit or reboot? How does anti-PD-1 therapy change tumor-infiltrating lymphocytes? Cancer Cell. 2019;36(3):215-7.

54. Yarnold J, Brotons MC. Pathogenetic mechanisms in radiation fibrosis. Radiother Oncol. 2010;97(1):149-61.

55. Chen Y, Rubin P, Williams J, Hernady E, Smudzin T, Okunieff P. Circulating IL6 as a predictor of radiation pneumonitis. Int J Radiat Oncol Biol Phys. 2001; 49(3):641-8

56. Rube CE, Palm J, Erren M, Fleckenstein J, Konig J, Remberger K, Rube C. Cytokine plasma levels: reliable predictors for radiation pneumonitis? PLOS One. 2008;3(8):e2898.

57. Oikonomou N, Harokopos V, Zalevsky J, Valavanis C, Kotanidou A, Szymkowski DE, Kollias G, Aidinis V. Soluble TNF mediates the transition from pulmonary inflammation to fibrosis. PLoS One. 2006;1:e108.

58. Dissanayake D, Hall H, Berg-Brown N, Elford AR, Hamilton SR, Murakami K, Deluca LS, Gommerman JL, Ohashi PS. Nuclear factor-kappaB1 controls the functional maturation of dendritic cells and prevents the activation of autoreactive T cells. Nat Med. 2011;17(12):1663-7.

59. Deng $L$, Liang $H$, Burnette $B$, Beckett $M$, Darga $T$, Weichselbaum RR, Fu YX. Irradiation and anti-PD-L1 treatment synergistically promote antitumor immunity in mice. J Clin Invest. 2014;124(2):687-95.

60. Sprung $\mathrm{CN}$, Forrester HB, Siva S, Martin OA. Immunological markers that predict radiation toxicity. Cancer Lett. 2015;368(2):191-7.

61. Buttner C, Skupin A, Reimann T, Rieber EP, Unteregger G, Geyer P, Frank KH. Local production of interleukin-4 during radiation-induced pneumonitis and pulmonary fibrosis in rats: macrophages as a prominent source of interleukin-4. Am J Respir Cell Mol Biol. 1997;17(3):315-25.

62. Wilson MS, Madala SK, Ramalingam TR, Gochuico BR, Rosas IO, Cheever AW, Wynn TA. Bleomycin and IL-1beta-mediated pulmonary fibrosis is IL-17A dependent. J Exp Med. 2010;207(3):535-52.

63. Lee CG, Homer RJ, Zhu Z, Lanone S, Wang X, Koteliansky V, Shipley JM, Gotwals $\mathrm{P}$, Noble $\mathrm{P}$, Chen $\mathrm{Q}$, et al. Interleukin-13 induces tissue fibrosis by selectively stimulating and activating transforming growth factor beta (1). J Exp Med. 2001;194(6):809-21.

64. Brickey WJ, Neuringer IP, Walton W, Hua X, Wang EY, Jha S, Sempowski GD, Yang X, Kirby SL, Tilley SL, et al. MyD88 provides a protective role in longterm radiation-induced lung injury. Int J Radiat Biol. 2012;88(4):335-47.

65. Benmerzoug $S$, Rose $S$, Bounab B, Gosset D, Duneau L, Chenuet $P$, Mollet $L$, Le Bert M, Lambers C, Geleff S, et al. STING-dependent sensing of self-DNA drives silica-induced lung inflammation. Nat Commun. 2018;9(1):5226.

66. Cameron BD, Sekhar KR, Ofori M, Freeman ML. The role of Nrf2 in the response to normal tissue radiation injury. Radiat Res. 2018;190(2):99-106.

67. Teng F, Meng X, Kong L, Yu J. Progress and challenges of predictive biomarkers of anti PD-1/PD-L1 immunotherapy: a systematic review. Cancer Lett. 2018:414:166-73.

68. Mazzaschi G, Facchinetti F, Missale G, Canetti D, Madeddu D, Zecca A, Veneziani M, Gelsomino F, Goldoni M, Buti S, et al. The circulating pool of functionally competent NK and CD8+ cells predicts the outcome of antiPD1 treatment in advanced NSCLC. Lung Cancer. 2019;127:153-63.

69. Riemann D, Cwikowski M, Turzer S, Giese T, Grallert M, Schutte W, Seliger B. Blood immune cell biomarkers in lung cancer. Clin Exp Immunol. 2019; 195(2):179-89.

70. Safi S, Yamauchi Y, Rathinasamy A, Stamova S, Eichhorn M, Warth A, Rauch $\mathrm{G}$, Dienemann $\mathrm{H}$, Hoffmann $\mathrm{H}$, Beckhove P. Functional T cells targeting tumor-associated antigens are predictive for recurrence-free survival of patients with radically operated non-small cell lung cancer. Oncoimmunology. 2017;6(11):e1360458.

71. Zhou G, Wang D, Liu D, Qi D, Liu Z. Expression of B and T Iymphocyte attenuator in patients with severe community-acquired pneumonia and the effect of steroid therapy in a mouse model. Clin Lab. 2016;62(12):2367-77. 
72. Mehrotra P, Collett JA, Gunst SJ, Basile DP. Th17 cells contribute to pulmonary fibrosis and inflammation during chronic kidney disease progression after acute ischemia. Am J Physiol Regul Integr Comp Physiol. 2018;314(2):R265-73.

73. Guo H, He Z, Li M, Wang T, Zhang L. Imbalance of peripheral blood Th17 and Treg responses in children with refractory Mycoplasma pneumoniae pneumonia. J Infect Chemother. 2016;22(3):162-6.

74. Piguet PF. Cytokines involved in pulmonary fibrosis. Int Rev Exp Pathol. 1993:34(Pt B):173-81.

75. Hashimoto S, Gon Y, Takeshita I, Matsumoto K, Maruoka S, Horie T. Transforming growth factor-beta1 induces phenotypic modulation of human lung fibroblasts to myofibroblast through a c-Jun-NH2-terminal kinase-dependent pathway. Am J Respir Crit Care Med. 2001;163(1):152-7.

76. Finkelstein JN, Johnston CJ, Baggs R, Rubin P. Early alterations in extracellular matrix and transforming growth factor beta gene expression in mouse lung indicative of late radiation fibrosis. Int J Radiat Oncol Biol Phys. 1994;28(3):621-31.

77. Rube CE, Uthe D, Schmid KW, Richter KD, Wessel J, Schuck A, Willich N, Rube $C$. Dose-dependent induction of transforming growth factor beta (TGF-beta) in the lung tissue of fibrosis-prone mice after thoracic irradiation. Int J Radiat Oncol Biol Phys. 2000;47(4):1033-42.

78. Rube $C E$, Rodemann HP, Rube $C$. The relevance of cytokines in the radiation-induced lung reaction. Experimental basis and clinical significance. Strahlenther Onkol. 2004;180(9):541-9.

79. Wolf J, Rose-John S, Garbers C. Interleukin-6 and its receptors: a highly regulated and dynamic system. Cytokine. 2014;70(1):11-20.

80. Eriksson E, Milenova I, Wenthe J, Moreno R, Alemany R, Loskog A. IL-6 signaling blockade during CD40-mediated immune activation favors antitumor factors by reducing TGF-beta, collagen type I, and PD-L1/PD-1. J Immunol. 2019;202(3):787-98.

81. Bradley J, Movsas B. Radiation pneumonitis and esophagitis in thoracic irradiation. Cancer Treat Res. 2006;128:43-64.

82. Haanen J, Carbonnel F, Robert C, Kerr KM, Peters S, Larkin J, Jordan K, Committee EG. Management of toxicities from immunotherapy: ESMO Clinical Practice Guidelines for diagnosis, treatment and follow-up. Ann Oncol. 2017;28(suppl_4):iv119-42.

83. Brahmer JR, Lacchetti C, Schneider BJ, Atkins MB, Brassil KJ, Caterino JM, Chau I, Ernstoff MS, Gardner JM, Ginex P, et al. Management of immunerelated adverse events in patients treated with immune checkpoint inhibitor therapy: American Society of Clinical Oncology clinical practice guideline. J Clin Oncol. 2018;36(17):1714-68.

84. Puzanov I, Diab A, Abdallah K, Bingham CO 3rd, Brogdon C, Dadu R, Hamad L, Kim S, Lacouture ME, LeBoeuf NR, et al. Managing toxicities associated with immune checkpoint inhibitors: consensus recommendations from the Society for Immunotherapy of Cancer (SITC) Toxicity Management Working Group. J Immunother Cancer. 2017;5(1):95.

85. Wang H, Liao Z, Zhuang Y, Xu T, Nguyen QN, Levy LB, O'Reilly M, Gold KA, Gomez DR. Do angiotensin-converting enzyme inhibitors reduce the risk of symptomatic radiation pneumonitis in patients with non-small cell lung cancer after definitive radiation therapy? Analysis of a single-institution database. Int J Radiat Oncol Biol Phys. 2013;87(5):1071-7.

86. Wang YS, Chang HJ, Chang YC, Huang SC, Ko HL, Chang CC, Yeh YW, Jiang JS, Lee CY, Chi MS, et al. Serum amyloid a as a predictive marker for radiation pneumonitis in lung cancer patients. Int J Radiat Oncol Biol Phys. 2013;85(3):791-7.

87. Li Y, Song LW, Peng RY, Wang DW, Jin MH, Gao YB, Ma JJ. Effects of SB203580 and WP631 on Smad signal transduction pathway in lung fibroblasts after irradiation. Ai Zheng. 2008;27(7):698-702.

88. Sekine I, Sumi M, Ito $Y$, Nokihara H, Yamamoto $N$, Kunitoh $H$, Ohe $Y$, Kodama T, Saijo N, Tamura T. Retrospective analysis of steroid therapy for radiation-induced lung injury in lung cancer patients. Radiother Oncol. 2006;80(1):93-7

\section{Publisher's Note}

Springer Nature remains neutral with regard to jurisdictional claims in published maps and institutional affiliations.

\section{Ready to submit your research? Choose BMC and benefit from:}

- fast, convenient online submission

- thorough peer review by experienced researchers in your field

- rapid publication on acceptance

- support for research data, including large and complex data types

- gold Open Access which fosters wider collaboration and increased citations

- maximum visibility for your research: over $100 \mathrm{M}$ website views per year

At BMC, research is always in progress.

Learn more biomedcentral.com/submissions 